\title{
Sistem Honorifik Bahasa Samawa dan Faktor Yang Memengaruhi Pemakaiannya
}

\author{
Nur Ifansyaha,1, Rini Qurratul Ainib,2 \\ aProgram Studi Pendidikan Bahasa dan Sastra Indonesia, FKIP, Universitas Samawa \\ bProgram Studi Pendidikan Bahasa dan Sastra Indonesia, FKIP, Universitas Samawa

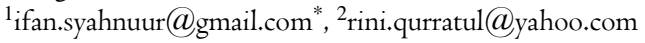

\begin{tabular}{ll}
\hline Informasi artikel & \\
\hline Sejarah artikel: & \\
Diterima & $: 06-02-2018$ \\
Revisi & $: 23-01-2019$ \\
Dipublikasikan & $:$ Januari 2019 \\
\hline
\end{tabular}

Kata kunci:

sistem honorifik

bahasa Samawa

pragmatik

kesantunan \begin{abstract}
ABSTRAK
Penelitian ini ditujukan untuk mendeskripsikan dan menjelaskan bentuk honorifik bahasa Samawa dan faktor yang memengaruhi pemakaiannya. Metode yang digunakan ialah studi kasus. Data bersumber dari penutur jati bahasa Samawa di Sumbawa yang dipilih secara purposif. Pengumpulan data dilakukan melalui wawancara mendalam dengan para informan. Untuk memastikan keabsahan data diterapkan triangulasi sumber data. Data dianalisis dengan model interaktif. Temuan penelitian menunjukkan bahwa (I) bentuk honorifik bahasa Samawa diklasifikasikan menjadi dua, yakni honorifik referen (pronomina persona pertama, pronomina persona kedua, dan pronomina persona ketiga), dan honorifik pendengar (hubungan kekerabatan, hubungan profesional, gelar, status perkawinan, dan nomina penyapa umum); (2) faktor yang memengaruhi pemakaian honorifik bahasa Samawa meliputi kekuasaan (jenis kelamin, usia, posisi dalam keluarga, pekerjaan, posisi dalam suatu institusi, status perkawinan, dan pendidikan), jarak (solidaritas, keakraban, dan perasaan), dan formalitas (tujuan dan latar).

ABSTRACT

The research intents on describing and explaining the honorifics forms of Samawa language and their use effect factors. The conducted method is case study. Source of data is native speaker of Samawa language in Sumbawa by purposive sampling. Data collection is conducted by in-depth interview with the informants. Data is analysed by interactive model. Furthermore, research findings present that (I) honorific forms of Samawa language is classified by two, they are referent honorific (first person pronoun, second person pronoun, and third person pronoun) and hearer honorific (family relation, professional relation, title, marital status, and general greeting nominal); (2) factor that affects the honorific use of Samawa language contains of power (sex, age, position in the family, occupation, position in an institution, marital status, and education), distance (solidarity, familiarity, and affect), and formality (purpose and setting).
\end{abstract}

\section{Key word:}

honorific system

Samawa language

Pragmatics

Politeness

\section{Pendahuluan}

Bangsa Indonesia yang kaya akan budaya daerah tentu memiliki karakteristik kesantunan yang beragam. Kesantunan berbahasa merupakan salah satu bentuk kearifan lokal. Kekayaan budaya daerah tersebut harus dikaji dan didokumentasikan secara ilmiah. Penelitian terhadap aspek-aspek kesantunan berbahasa perlu dilakukan, sebagaimana diungkapkan Holmes (2013), bahwa kesantunan memberikan kontribusi dalam menciptakan harmoni sosial dan menghindari konflik sosial.

\section{Copyright (C) 2018 Universitas Ahmad Dahlan. All Right Reserved}

Salah satu aspek kesantunan ialah penggunaan honorifik atau sebutan ketakziman. Aspek ini merupakan formula kesantunan dalam bahasa tertentu yang secara spesifik dapat berbentuk afiks, kata, atau struktur kalimat (Richards dan Schmidt, 2010).

Brown (20II) mendefinisikan honorifik sebagai sumber daya untuk mengindeks posisi relatif mitra bicara, referen, dan orang di sekitar. Bentuk honorifik berupa leksikon atau morfo-sintaksis dalam suatu bahasa. Honorifik merupakan bagian sentral deiksis sosial atau indeksikalitas. Honorifik 
didefinisikan sebagai istilah untuk aspek struktur bahasa yang menyandikan identitas sosial partisipan, atau hubungan sosial di antara mereka, atau antara salah satu dari mereka dan orang-orang atau entitas yang diacu (Levinson, 1983). Honorifik juga merujuk pada (kurang lebih) fenomena yang sama, tetapi dalam kerangka yang lebih luas dari komunikasi dan pemikiran yang bergantung pada konteks (Levinson, 2004).

Penelitian ihwal honorifik pernah dikerjakan oleh Brown (20II). Brown melakukan studi pragmatik antarbahasa dengan menggunakan metode campuran untuk menyelidiki penggunaan honorifik bahasa Korea oleh para penutur bahasa Korea (sebagai bahasa kedua) dengan latar belakang "Barat". Di dalam laporannya dijelaskan bahwa honorifik dapat dibagi menjadi tiga kategori, yakni (a) honorifik referen (referenthonorifics), (b) honorifik pendengar (hearerhonorifics), dan honorifik orang di sekitar (bystanderhonorifics). Honorifik referen menunjuk pada hubungan antara pembicara dan referen dalam kalimat (atau sebaliknya, hubungan antarreferen yang berbeda). Referen mungkin diri pendengar sendiri atau orang ketiga. Honorifik pendengar secara langsung menunjuk pada hubungan antara pembicara dan pendengar dan tidak memerlukan pendengar untuk terlihat sebagai referen kalimat. Honorifik orang di sekitarmenunjuk pada kehadiran orang lain di tempat peristiwa tutur. Bentuk-bentuk yang sesuai untuk berbicara di hadapan orang yang bersangkutan belum tentu tepat ketika berbicara tentang atau kepadanya (Brown, 20II).

Terdapat beberapa kajian lainnya ihwal honorifik bahasa-bahasa di dunia, seperti Izadi (2015) meneliti peran honorifik bahasa Persiadalam evaluasi ke(tak)santunan yang muncul dalam interaksi lokal dengan menggunakan analisis percakapan; Burdelski membahas sosialisasi honorifik bahasa Jepang dalam interaksi di rumah tangga dan prasekolah mengenai bagaimana pengasuh menggunakan honorifik kepada anak-anak dan bagaimana anak-anak menggunakan honorifik kepada pengasuh dan teman sebaya; Min, Meng, dan Ying (2016), melakukan perbandingan lintas budaya melalui honorofik dalam bahasa Cina modern dan bahasa Inggris-Amerika;Han, Sohn, dan Yoo menjelaskan tentang sistem honorifik bahasa Korea dan pengaruhnya dalam periklanan; dan Bhatt (2015), mengkaji sistem honorifik bahasa Hindi (representasi morfologisnya dalam bentuk kata benda, kata ganti, kata sifat, dan kata kerja, yang mencerminkan hubungan yang terjalin di antara individu-individu didasarkan pada formalitas, keakraban, usia, hubungan keluarga, status sosial, kasta, dan faktor sosial lainnya).

Merujuk pada kategori Brown (20II), Rejeki (2015) mendeskripsikan bentuk honorifik bahasa Duanu di Provinsi Riau. Temuannya menunjukkan bahwa bentuk honorifik bahasa Duanu dapat dikategorikan ke dalam (a) honorifik referen, meliputi kata ganti orang pertama, kata ganti orang kedua, dan kata ganti orang ketiga, dan (b) honorifik pendengar, meliputi honorifik dalam hubungan kekerabatan, hubungan profesional, dan hubungan sosial. Adapun pemakaian bentuk-bentuk honorifik tersebut dipengaruhi oleh beberapa faktor, yakni (a) kekuasaan (jenis kelamin, usia, posisi dalam keluarga, jabatan, posisi dalam sebuah institusi, status perkawinan, pendidikan, dan keberadaan tokoh supranatural atau makhluk gaib); (b) jarak sosial (solidaritas, keakraban, dan perasaan); dan (c) formalitas (tujuan dan latar belakang) (Rejeki, 2015).

Honorifik bahasa Samawa (secara khusus) sekarang ini belum pernah diteliti. Adapun upaya yang dikerjakan oleh Kasman (2013) mengenai penggunaan honorifik bahasa Samawa hanya sebagai salah satu anasir pemengaruh atau penentu kesantunan berbahasa, bukan sebagai objek yang dikaji secara utuh dan terfokus.

Penelitian ini ditujukan untuk mendeskripsikan dan menjelaskan bentuk honorifik bahasa Samawa dan faktor yang memengaruhi pemakaiannya. Hasil penelitian ini dapat memperkaya khazanah ilmu pragmatik, terkhusus ihwal sistem honorifik, dan dapat dimanfaatkan sebagai acuan dalam pembelajaran pragmatik di perguruan tinggi.

\section{Metode}

Penelitian ini merupakan studi kasus terhadap sistem honorifik bahasa Samawa di Sumbawa Besar. Data bersifat kualitatif dan bersumber dari sepuluh orang penutur jati bahasa Samawa. Pemilihan informan didasarkan atas teknik penyampelan purposif. Data dikumpulkan melalui wawancara mendalam. Keabsahan data diuji dengan triangulasi sumber data. Analisis data dilakukan dengan menerapkan model interaktif yang terdiri atas tiga komponen, meliputi penyingkatan data (data condensation), penyajian data (data display), dan penarikan dan verifikasi simpulan (drawing and verifying conclusions) (Miles, Huberman, dan Saldana, 20I4). 


\section{Hasil dan pembahasan}

\section{A. Bentuk Honorifik Bahasa Samawa}

Bahasa Samawa memiliki beraneka bentuk honorifik. Bentuk-bentuk yang ditemukan dapat diklasifikasikan ke dalam dua kategori: (I) honorifik referen: pronomina persona pertama, pronomina persona kedua, dan pronomina persona ketiga, dan (2) honorifik pendengar: hubungan kekerabatan, hubungan profesional, gelar, status perkawinan, dan nomina penyapa umum.

\section{Honorifik Referen}

Honorifik referen diwujudkan melalui pemakaian pronomina. Pronomina merupakan kata yang digunakan untuk mengganti nama diri, baik diri sendiri, mitra tutur, maupun orang lain yang tidak terlibat di dalam percakapan. Atas dasar itu, honorifik referen dibagi menjadi tiga jenis, meliputi pronomina persona pertama, pronomina persona kedua, dan pronomina persona ketiga.

Pronomina persona pertama yang menunjukkan honorifik ialah kaji, saya, dan kajulen. Pemakaian kaji merujuk kepada diri sendiri sebagai bentuk penghormatan kepada orang yang usianya lebih tua atau memiliki posisi yang lebih tinggi dalam silsilah keluarga, misalnya keponakan kepada pamannya, meskipun usia pamannya lebih muda darinya. Sementara itu, saya merupakan bentuk serapan dari bahasa Indonesia dengan makna yang sama. Jika di dalam bahasa Indonesia bernilai rasa netral, di dalam bahasa Samawa kata saya cenderung bernilai rasa positif. Penggunaannya mengandung unsur hormat kepada mitra bicara. Berbeda dengan kaji, penggunaan pronomina saya umumnya dijumpai pada percakapan yang dilangsungkan oleh penutur yang terdidik. Meskipun begitu, dalam konteks tertentu keduanya dapat saling menggantikan. Pronomina kajulen mengandung nilai hormat yang lebih tinggi dari kedua kata sebelumnya. Kajulen berasal dari kata kaji 'saya' dan ulen 'hamba', sehingga menjadi 'saya hamba'. Ditilik dari aspek semantisnya, kata kajulen mengandung makna pengakuan tentang posisi atau status si penutur yang lebih rendah dibandingkan mitra tuturnya. Pronomina ini dipilih ketika berhadapan dengan orang-orang yang status sosial atau pangkatnya lebih tinggi, misalnya raja atau pejabat-pejabat lainnya. Tidak hanya itu, kajulen juga digunakan ketika berkomunikasi dengan orang yang telah berhaji. Hal ini menyiratkan pengertian bahwa kata ulen bukan lagi bermakna 'hamba' atau 'abdi', melainkan lebih mendalam dari itu, yakni adanya kesadaran tentang kekurangan atau ketidaksempurnaan dirinya jika dibandingkan dengan mitra tutur.
Pronomina persona kedua yang tergolong honorifik cukup banyak. Adapun kata yang termasuk ke dalam jenis ini, meliputi dirinan, sia, kelam, dan sareasia atau sia sarea. Pronomina dirinan merupakan kata untuk mengganti nama diri mitra tutur yang sebaya. Pronomina dirinan merupakan gabungan dari diri 'diri seseorang' dan bentuk deiktis nan 'itu'. Pronomina sia, kelam, dan sareasiaatau siasareagalibnya ditujukan untuk mengganti nama diri mitra tutur yang usianya lebih tua. Sia dan kelam yang sama-sama berarti 'anda' (bernilai rasa hormat) merupakan bentuk tunggal, sedangkan sareasiaatau sia sarea anda semua/sekalian' digunakan untuk pendengar yang jamak. Meskipun sama-sama mengandung unsur penghormatan, kelam memiliki tingkat penghormatan yang lebih tinggi dibandingkan sia.

Pronomina persona ketiga yang merupakan honorifik ialah diri. Pronomina ini sama seperti beliau di dalam bahasa Indonesia. Selain digunakan dalam bentuk dasar, pronomina diri juga kerap kali dilekatkan dengan bentuk deiktis penunjuk tempat atau arah, yakni ta, to, dan ana. Dirita merujuk pada orang ketiga yang berada dekat dengan penutur. Bersamaan dengan penyebutan pronomina diri ta, penutur biasanya melakukan kontak fisikmenyentuh, memegang, atau menepuk-terhadap orang yang dimaksud. Dirito merujuk pada orang ketiga yang berada agak jauh dari kedua pelibat dan tidak terlibat langsung di dalam pertuturan. Meskipun begitu, keberadaannya masih di sekitar pertuturan dan terjangkau oleh penglihatan masingmasing pelibat. Diriana merujuk pada orang ketiga yang berada jauh dari pelibat maupun peristiwa tutur, sehingga tidak terjangkau oleh penglihatan mereka.

\section{Honorifik Pendengar}

Honorifik ini mencakupi beberapa kategori, meliputi hubungan kekerabatan, hubungan profesional, gelar, status perkawinan, dan nomina penyapa umum. Beberapa kategori tersebut melahirkan beragam bentuk ungkapan penghormatan.

Pentakziman kepada orang lain melalui bahasa sangat mudah dijumpai pada lingkungan keluarga atau kekerabatan. Adapun bentuk honorifik yang termasuk ke dalam jenis ini, meliputi (I) hubungan keluarga secara langsung: balo (buyut); papen/abe/pape (kakek/nenek); ua, bapak, aba, mameng (bapak); ina, emak (ibu); paman (paman), bibi (bibi), ea (paman/bibi yang usianya lebih tua dari bapak/ibu),nde (paman/bibi yang usianya lebih muda dari bapak/ibu); kakak (kakak lakilaki/perempuan dan kakak sepupu laki- 
laki/perempuan); adi (adik laki-laki/perempuan dan adik sepupu laki-laki/perempuan); duan (keponakan); papu (cucu); balo (cicit); dan (2) tidak langsung: ua, bapak, aba, mameng (bapak mertua); ina, emak (ibu mertua); kakak (kakak ipar lakilaki/perempuan); adi (adik ipar lakilaki/perempuan).

Entitas yang berkaitan dengan hubungan profesional, seperti profesi dan jabatan, dapat memengaruhi pemilihan penanda honorifik yang ditujukan kepada orang-orang yang berprofesi. Orang biasanya dipanggil dengan nama profesi atau jabatan yang dimiliki. Adapun honorifik yang berkaitan dengan profesi, misalnya pak guru, bu guru, pak dosen, bu dosen, pak tentara, pak polisi, bu bidan, dan sebagainya. Honorifik yang berkaitan dengan jabatan sepertipakrektor, pakbupati, pakdandim, pakkadis, bukasek, pakkasek, gabung 'kepala desa', penggawa/nakoda 'kapten/pemimpin pada kapal (penangkap ikan dsb.)', juragan 'kapten sekaligus pemilik kapal', dan sebagainya. Nomina pak merupakan serapan dari bahasa Indonesia dengan bentuk yang sama yang merupakan pendekan dari bapak. Bentuk lengkap bapak sebagai nomina penyapa umum tidak terserap ke dalam bahasa Samawa. Nomina bapak yang terdapat di dalam bahasa Samawa merupakan istilah kekerabatan untuk orang tua laki-laki.

Penggunaan gelar sebagai bentuk penghormatan dalam bahasa Samawa terdiri atas gelar religi, gelar akademik, gelar kebangsawanan, dan gelar tradisional. Gelar religi dalam hal ini berkenaan dengan agama Islam karena mayoritas penduduk Sumbawa merupakan muslim dan secara historis peradaban masyarakat Sumbawa tidak dapat dilepaskan dari ajaran Islam. Adapun gelar yang digunakan sebagai bentuk penghormatan, yaitu ustad 'ustaz' (pendakwah atau orang alim), deaguru 'guru ngaji', haji 'haji', hajah 'hajah', nyai 'istri haji yang belum menjadi hajah', lebe, dealebe, atau deaimam 'imam masjid', ketip 'khatib', bilal 'muazin atau bilal', dan marbat 'marbut'. Penyebutan gelar biasanya juga diikuti dengan nama yang bersangkutan, misalnya UstadAmin, HajiUsin, LebeAsan, dan MarbatBore.

Gelar akademik yang digunakan untuk menyapa seseorang sebagai bentuk penghormatan, misalnya, insinyur, pak/budoktor, doktor, dan prof. (Meskipun jabatan akademik, prof 'profesor' di sini digeneralisasi sebagai gelar.).

Gelar yang ketiga ialah gelar kebangsawanan. Adanya gelar ini tidak lepas dari sejarah awal pemerintahan Sumbawa yang berbentuk kerajaan. Sebagaimana umumnya sebuah kerajaan, struktur sosial yang terbentuk setidaknya terdiri atas lapisan rakyat jelata dan bangsawan. Gelar merupakan salah satu bentuk keistimewaan yang dimiliki kaum bangsawan. Tiap gelar yang disandang menandai posisi dan status sosial mereka. Gelar kebangsawanan yang menandai adanya penghormatan seperti dea, lalu, lala, dan daeng. Ketiga gelar tersebut merujuk kepada kaum bangsawan: dea(bangsawan laki-laki dan perempuan secara keseluruhan), lalu (bangsawan laki-laki keturunan datur raja' yang menikah dengan sesama keturunan datu), lala (bangsawan perempuan keturunan datu yang menikah dengan sesama keturunan datu), dan daeng (bangsawan laki-laki dan perempuan keturunan datu).

Aktivitas keseharian masyarakat Sumbawa sangat erat kaitannya dengan tradisi. Dalam konteks ini, pada beberapa pihak disematkan gelar tertentu sesuai dengan peran yang dijalankan di tengah masyarakat. Gelar yang dimaksud merupakan gelar tradisional, seperti sandro, malar, dan tukang. Namanama tersebut merupakan nama peran sekaligus gelar yang dilekatkan kepada yang bersangkutan. Sandro 'tabib/dukun' merupakan gelar yang diberikan oleh masyarakat kepada orang yang memiliki kemampuan untuk menyembuhkan orang dari penyakit atau menolong wanita yang sedang melahirkan. Malar merupakan gelar yang diberikan kepada orang yang bertugas mengatur lalu lintas air untuk keperluan irigasi. Tukang merupakan orang yang memiliki suatu kepandaian dalam pekerjaan tangan tertentu. Terdapat beberapa macam tukang, seperti tukang tepungtukang kue', tukang baletukang rumah', tukang jangan 'tukang ikan atau lauk-pauk pada suatu acara', tukang/panre besi pandai besi', dan tukang/panre emas 'pandai emas'.

Status perkawinan menyebabkan adanya bentuk honorifik tertentu yang digunakan untuk menyapa atau mengacu kepada orang-orang yang telah memiliki status itu sekaligus membedakannya dengan orang yang masih lajang. Di dalam bahasa Samawa, orang yang telah kawin dan memiliki anak akan disebut dengan nama anak tertuanya (perempuan atau laki-laki) yang didahului istilah kekerabatan untuk orang tua, misalnya ua/bapak/aba (nya) Adam'bapaknya Adam', ua/bapak/aba (sI) Ranibapaknya Rani', ina/ emak (nya) Adamibunya Adam', dan ina/emak (si) Rani 'ibunya Rani'. Artikel nya dan si digunakan secara opsional untuk memarkahi jenis kelamin:nyasebagai pemarkah jenis kelamin laki-laki dan si sebagai pemarkah jenis kelamin perempuan. Contoh bentuk tersebut digunakan pula oleh suami atau istri untuk menyapa atau mengacu kepada istri atau suaminya. Bentuk lain yang sering digunakan sebagai acuan ialah taupangbale atau taumbale 'orang di rumah' (suami atau istri sebagai acuan). 
Nomina penyapa umum lazim digunakan untuk menghormati orang lain. Istilah "umum" digunakan untuk menandai bahwa bentuk-bentuk honorifik yang termasuk di dalamnya dikecualikan dari kategori yang lain, meskipun istilah yang digunakan masih berhubungan, khususnya istilah kekerabatan. Selain dengan istilah kekerabatan, bentuk honorifik ini juga terkait dengan istilah dalam relasi interpersonal. Nomina penyapa di dalam bahasa Samawa yang digunakan untuk keperluan tersebut terdiri atas papen/abe/pape 'kakek/nenek', paman 'paman', bibi 'bibi', kakak 'kakak', adi 'adik', sanak salaki 'saudara laki-laki', sanaksawai 'saudaraperempuan', dan kanti 'sahabat'. Honorifik nomina penyapa umum tersebut dapat digunakan untuk orang yang akrab, dikenal, maupun belum dikenal yang didasarkan atas perbedaan jenis kelamin dan usia.

\section{B. Faktor yang Memengaruhi Pemakaian Honorifik Bahasa Samawa}

Pemakaian honorifik dalam bahasa Samawa dipengaruhi oleh beberapa faktor, seperti kekuasaan, jarak, dan formalitas. Berikut uraian masing-masing faktor tersebut.

\section{Faktor Kekuasaan}

Pemakaian honorifik berdasarkan faktor pertamaini dipengaruhi oleh pendengar atau pihak yang diacu yang secara sosial superior/inferior terhadap pembicara. Superioritas atau inferioritas menunjukkan adanya kekuasaan, yakni hubungan vertikal yang ditandai oleh adanya pihak yang lebih berkuasa dari pihak lainnya. Perbedaan kekuasaan ini umumnya dinyatakan dalam bentuk status atau peringkat (rank). Diamond (1996: 9) membagi peringkat menjadi dua komponen, yakni peringkat institusional dan peringkat lokal. Peringkat institusional menyangkut tatanan sosial yang relatif tetap yang biasanya mencakupi jenis kelamin, usia, ras, dan posisi dalam keluarga. Peringkat lokal mencakup faktor-faktor seperti pekerjaan, posisi pada suatu institusi, ekonomi, status perkawinan, dan pendidikan. Peringkat yang kedua ini, setidaknya secara teoretis, dapat diubah dengan usaha individu, meskipun akan bergantung pada variabel lokal dan kultural.

Pemakaian bentuk honorifik bahasa Samawa dipengaruhi oleh kedua peringkat di atas. Peringkat institusional yang memberikan pengaruh meliputi jenis kelamin, usia, dan posisi dalam keluarga. Pemakaian honorifik yang dipengaruhi oleh faktor jenis kelamin tampak pada bentuk honorifik nyai yang berarti istri haji yang belum menjadi hajah. Imbangan bentuk itu untuk laki-laki tidak ditemukan karena dalam kebiasaan masyarakat Sumbawa, laki-laki atau suami cenderung lebih didahulukan untuk urusan berhaji dibandingkan perempuan atau istri. Faktor usia tampak pada pemilihan bentuk dirinan dan sia atau kelam. Ketiga bentuk honorifik tersebut sama-sama sebagai pronomina persona kedua tunggal, tetapi berbeda pemakaiannya. Perbedaan itu didasarkan atas perbedaan usia mitra bicara terhadap pembicara. Bentuk honorifik dirinan digunakan jika mitra bicara sebaya dengan pembicara, sedangkan bentuk honorifik sia dan kelam digunakan jika usia mitra bicara lebih tua dibandingkan pembicara. Pengaruh posisi dalam keluarga tampak pada bentuk honorifik dalam hubungan kekerabatan. Posisi seseorang dalam silsilah keluarga menentukan bentuk honorifik yang digunakan untuk menyapanya dan yang ia gunakan untuk menyapa mitra bicara yang merupakan bagian dari keluarga yang sama atau berkerabat dengan pembicara.

Peringkat lokal yang berpengaruh meliputi pekerjaan, posisi dalam suatu institusi, status perkawinan, dan pendidikan. Jenis pekerjaan dapat menentukan bentuk honorifik yang digunakan. Sebagai misal, seseorang yang bekerja sebagai guru akan disapa dengan pakguru atau buguru. Jika yang bersangkutan beralih profesi, dimungkinkan akan dipanggil dengan nama profesinya yang baru. Pengaruh posisi dalam suatu institusi terhadap pemakaian bentuk honorifik, misalnya, tampak pada pemakaian bentuk honorifik pakkabag, jika memang yang bersangkutan memiliki jabatan sebagai kepala bagian pada suatu dinas. Bentuk honorifik yang digunakan untuk menyapanya akan berubah, misalnya menjadi pak kadis, apabila ia mengalami perubahan jabatan atau posisi menjadi kepala pada institusi kedinasan tersebut. $\mathrm{Di}$ dalam bahasa Samawa sebetulnya tidak dikenal sebutan atau sapaan khusus untuk laki-laki atau perempuan yang telah kawin. Namun, ketika mereka memiliki anak, umumnya disapa dengan nama anak tertuanya yang didahului istilah kekerabatan untuk orang tua bapak/ibu, misalnya Bapak Nya Amir'Bapak Si Amir' dan EmakNyaAmir'Ibu Si Amir'. Pengaruh faktor pendidikan tampak pada pemakaian bentuk honorifik saya. Bentuk ini umumnya digunakan oleh orang yang terpelajar. Pengaruh faktor ini juga tampak pada pemakaian honorifik gelar. Beberapa bentuk honorifik gelar, seperti prof, pak/bu doktor, dan insinyur, didasarkan atas pencapaian atau level akademik orang yang menyandangnya setelah menempuh proses yang dipersyaratkan. 


\section{Faktor Jarak}

Pemakaian honorifik dipengaruhi oleh hubungan horizontal-simetris antarpartisipan dalam suatu peristiwa tutur. Hubungan ini diukur dari jarak yang memuat tiga aspek, meliputi solidaritas (solidarity), keakraban (familiarity), dan perasaan (affect). Solidaritas melibatkan kesamaan yang dirasakan atau yang dimiliki oleh para partisipan terlepas dari peringkat, misalnya keluarga yang sama, kampung yang sama, perusahaan yang sama, dan sebagainya. Keakraban mengacu pada kedekatan yang bisa dirasakan oleh partisipan semata-mata dari intensitas interaksi di antara mereka. Hal ini terutama mencakup lamanya partisipan saling mengenal satu sama lain dan waktu yang mereka habiskan dalam kedekatan. Memang, kedua hal ini tidak berkorelasi langsung dengan menjadi akrab. Hal-hal lainnya juga penting, seperti konteks di mana mereka berinteraksi, jenis peristiwa, dan hal lain yang mereka alami bersama. Meningkatnya keakraban memungkinkan pengenduran (relaksasi) honorifik, meskipun terbatas pada perbedaan kekuasaan yang kecil. Perasaan merujuk pada seberapa besar pembicara menyukai atau tertarik satu sama lain. Pada kasus tertentu, pembicara mungkin lebih berhati-hati untuk menerapkan bentuk honorifik kepada orang-orang yang tidak mereka sukai, terutama jika mitra bicaranya berstatus superior.

Faktor jarak, seperti solidaritas, keakraban, dan perasaan, ikut memengaruhi pemakaian honorifik dalam bahasa Samawa. Kesamaan, seperti keluarga, usia, jenis kelamin, kampung, dan pekerjaan, yang dimiliki oleh masyarakat tutur bahasa Samawa memberikan pengaruh terhadap pemakaian honorifik. Mereka yang memiliki kesamaan itu cenderung memilih bentuk tuturan dengan gaya normal. Menjadi bagian dari suatu kelompok yang sama, misalnya nelayan dan petani, membuat orangorang di dalamnya memiliki solidaritas dan rasa setara satu sama lain, sehingga berimplikasi pada kesetaraan dalam berkomunikasi. Gaya normal akan dipilih dalam hal ini dibandingkan bentuk honorifik. Berbeda halnya jika mereka memiliki jarak-dalam hal usia, jenis kelamin, pendidikan, dan lain-lain, yang cenderung menuntut untuk menggunakan bentuk honorifik tertentu. Hal ini menunjukkan bahwa solidaritas memengaruhi pemakaian honorifik. Pengaruh keakraban, misalnya, terlihat pada contoh bentuk honorifik pakdoktor. Dalam keadaan yang lebih akrab akan digunakan doktor atau hanya menyebut nama. Hal ini terjadi jika kedua partisipan memiliki usia yang sebaya. Pemakaian bentuk honorifik dalam hubungannya dengan perasaan (affect) tampak pada pemakaian bentuk nomina penyapa umum sanaksalaki 'saudara laki-laki', sanaksawai 'saudara perempuan', dan kanti 'sahabat'. Ketiga bentuk honorifik ini ditujukan untuk menunjukkan hubungan interpersonal yang dekat, sekalipun kenyataannya baru saling mengenal. Pemakaian bentuk ini oleh penutur menyiratkan maksud kepada mitra tutur bahwa penutur mengasumsikannya seolah-olah sebagai saudara atau sahabat karibnya, sehingga mereka dapat saling berkomunikasi dan berhubungan tanpa ada sekat atau rasa tidak nyaman.

\section{Faktor Formalitas}

Formalitas berkenaan dengan level penataan adegan (scene) di mana suatu interaksi terjadi. Brown dan Fraser (1979: 45) menyebut bahwa adegan berisi dua aspek: tujuan dan latar. Tujuan mencakup jenis kegiatan dan pokok bahasan yang melibatkan partisipan. Latar mencakup aspek fisik dan temporal serta, secara kritis, ke(tidak)hadiran pendengar yang banyak atau orang ketiga. Persoalan formalitas dalam pemakaian honorifik bahasa Samawa, misalnya, tampak pada retorika di dalam acara resmi, seperti rapat di Balai Desa, sambutan acara perkawinan, dan sebagainya. Pembicara akan memilih bentuk honorifik ina-bapak dibandingkan emak-uaq untuk menyapa hadirin yang lebih tua, meskipun memiliki arti yang sama, yakni 'ibu-bapak'. Hal ini disebabkan oleh faktor tujuan dan latar tertentu. Perbedaan latar memengaruhi pemilihan bentuk honorifik pronomina persona ketiga (diri) yang dilekatkan dengan bentuk deiktis ta, to, dan ana. Dirita digunakan untuk merujuk pada orang ketiga yang dekat penutur; dirito merujuk pada orang ketiga yang agak jauh dari penutur dan mitra tutur; diriana merujuk pada orang ketiga yang jauh dari penutur dan mitra tutur. Pemakaian ketiganya didasarkan atas perbedaan jarak fisik antara orang ketiga dan partisipan (penutur dan mitra tutur).

\section{Simpulan}

Bahasa Samawa memiliki sistem honorifik yang sangat kaya. Temuan ini mengindikasikan bahwa bahasa Samawa merupakan salah satu bahasa daerah yang memiliki daya ungkap kesantunan yang tinggi. Kesantunan yang ditunjukkan melalui bentuk-bentuk honorifik inheren dengan pelbagai ranah kehidupan. Kesadaran yang tinggi untuk senantiasa menggunakan bentuk-bentuk honorifik sesuai dengan tuntutan konteksnya sangat diperlukan dari anggota masyarakat tutur bahasa Samawa, sehingga nilai-nilai kesantunan yang menjadi khazanah budaya Sumbawa dapat dilestarikan. Penghormatan dalam berkomunikasi melalui pemakaian bentuk honorifik berkontribusi dalam menciptakan hubungan yang 
harmonis antarpartisipan (dan masyarakat Sumbawa, secara luas).

\section{Ucapan terima kasih}

Artikel ini merupakan salah satu bentuk keluaran dari penelitian penulis yang berjudul "Sistem Honorifik Bahasa Samawa dan Implikasinya dalam Pembelajaran Pragmatik di Program Studi Pendidikan Bahasa dan Sastra Indonesia”. Penulis berterima kasih kepada DRPM Direktorat Jenderal Penguatan Riset dan Pengembangan Kemristekdikti yang telah mendanai penelitian tersebut melalui skema Penelitian Dosen Pemula (PDP).

\section{Referensi}

Bhatt, Sunil Kumar. (2015). "Acquisition of Honorifics in Hindi: A Sociolinguistic Competence." Electronic Journal of Foreign Language Teaching, I2 (I), 37 I-380.

Brown, Lucien. (20II). Korean Honorifics and Politeness in Second Language Learning. Amsterdam: John Benjamins Publishing Company.

Holmes, Janet. (2013). An Introduction to Sociolinguistics. New York: Routledge.

Izadi, Ahmad. 2015. "Persian Honorifics and $\mathrm{Im} /$ Politeness as Social Practice." Journal of Pragmati cs , 85, 8I-9I.

Kasman. (2013). "Prinsip Sopan Santun dalam Bahasa Samawa.” Dalam Kundaru Saddhono dkk. (Ed.). Proceeding Seminar Internasional: Pengembangan Peran Bahasa dan Sastra Indonesia untuk Mewujudkan Generasi Berkarakter (hal.423-427). Surakarta: Program Studi Pendidikan Bahasa dan Sastra Indonesia FKIP UNS.

Levinson,Stephen C. (I983). Pragmatics. Cambridge: Cambridge University Press.

Levinson, Stephen C. (2004). "Deixis." Dalam Laurence R. Horn dan GregoryWard (Ed.). The Handbook of Pragmatics (hal. 97-I2I). Oxford: Blackwell.

Miles, M.B., Huberman, A.M., \& Saldana, J. (20I4). Qualitative Data Analysis: A Methods Sourcebook ( $3^{\text {rd }}$ ed.). Thousand Oaks, California: Sage Publications, Inc.

Min, Hui, Meng, Meng, dan Ying, Hui. (2016). "A Cross-Cultural Analysis of Honorifics in Modern Chinese and American English." Cross-Cultural Communication, I2 (II), 7I5.

Rejeki, Sri dan Zamzani. (2015). "The Honorifics of Duanu Language and Their Implications in English Teaching and Learning Contexts." Baster: Bahasa, Sastra, dan Terjemahan, I (I), 82-92.

Richards, Jack C. dan Schmidt, Richard. (2010). Longman Dictionary of Language Teaching and Applied Linguistics. Harlow: Pearson Education Limited. 